orphanage $A$ but not to the others, and we continued to weigh and measure the children for another 6 months. During the first half year the children in home A gained three times as much weight as those in home $B$, although their rations were the same. The children in home $A$ then received the extra bread, but from the time they began to eat it they grew more slowly, and the children in the other home B, who got no extra food, began to gain weight at a much faster rate. We knew that the children in home A ate the extra bread, for we weighed all their food, and their calorie intakes were $20 \%$ higher during the second 6 months than the first, and yet they gained less weight. Are we to conclude that extra brown bread stops children growing, or was there some other factor at work which was outweighing any beneficial effects of the extra calories we were providing?

At the beginning of the investigation home B was presided over by Fräulein Schwarz. Just at the time when we began to give the extra bread to the children in home $A$, the authorities transferred Fräulein Schwarz from home B to home A. Fräulein Schwarz was a very harsh, unsympathetic woman, and children and staff lived in constant fear of her reprimands and criticisms, which were often quite unreasonable. She chose mealtimes to scold the children publicly and she would single out individual children for special ridicule. By the time she had finished the food would be cold, all the children would be in a state of agitation and several would often be in tears. Anyone who is embarking on human experiments will do well to remember 'Better is a dinner of herbs where love is, than a stalled ox and hatred therewith' (Proverbs, 15, I7).

\title{
REFERENCES
}

Bernard, M. C. (1865). Intraduction a l'Étude de la Médicine Expérimentale. Paris: J. B. Baillière et fils. Krebs, H. A. \& Mellanby, K. (1942). Lancet, 242, 3 r9.

McCance, R. A. \& Widdowson, E. M. (1942a). 7. Physiol. Ior, 44 .

McCance, R. A. \& Widdowson, E. M. (1942b). F. Physiol. ror, 304.

McCance, R. A. \& Widdowson, E. M. (1946). Spec. Rep. Ser. med. Res. Coun., Lond., no. 254.

Widdowson, E. M. (1951). Lancet, 260, 1316.

Widdowson, E. M. \& McCance, R. A. (1954). Spec. Rep. Ser. med. Res. Coun., Lond., no. 287.

\section{The report of the panel on flour}

\section{By R. A. Morton, Department of Biochemistry, The University, Liverpool}

The Panel on Composition and Nutritive Value of Flour was appointed in May 1955 by the Secretary of State for Scotland, the Minister of Agriculture, Fisheries and Food and the Minister of Health. The members of the Panel were nominated at the request of the Minister of Agriculture, Fisheries and Food by the President of the Royal Society (Lord Adrian, O.M.). The Chairman was Professor Sir Henry Cohen (now Lord Cohen of Birkenhead) and the other members were Dr A. C. Chibnall, Professor J. H. Gaddum, Professor R. A. Morton and Professor L. J. Witts (Great Britain. Parliament, I956). 
The terms of reference were:

'In the light of the scientific and medical evidence now available-

(I) to determine the differences in composition and nutritive value between

(a) National flour as defined in the Flour Order, I953;

(b) flour of extraction rates less than National flour as defined in the Flour Order, I953, to which the three token nutrients have been restored;

(c) flour of extraction rates less than National flour as defined in the Flour Order, I953, to which the three token nutrients have not been restored; and

(2) to advise whether any such differences are significant from the point of view of the health of the population.'

The Panel was an independent body and its function was to review the scientific and medical evidence then available with the aim of assisting the Government to act in the general interest.

The inquiry was made necessary by persistent marked differences of opinion among people concerned directly or indirectly with nutrition and nutritional policy.

Before the war straight-run white flour of $72 \%$ extraction was in general use. In relation to whole grain such flour was a poor source of vitamins of the B complex. In July I940 the Government approved the policy of adding synthetic thiamine to flour and by 1942 about two-fifths of the white flour was being so enriched. Shortage of wheat then made it necessary to raise the extraction rate to $85 \%$. The resulting flour was rather dark but was richer in vitamins $B$ than white flour and it was not thought necessary to add thiamine. In October 1944 the supply of wheat made it possible to reduce the extraction rate to $82 \%$ and by improved techniques to retain in the flour a good proportion of the vitamin content of the grain. Investigations carried out at the Cereals Research Station (St. Albans) led to methods of milling which in January I945 resulted in a nearly white $80 \%$ extraction flour which contained a reasonable proportion of the vitamins present in the whole grain. In the early postwar years the extraction rate had again to be raised; it was at $90 \%$ for 4 months in 1946 , then at $85 \%$ until August 1950 when it was lowered to $80 \%$.

In 1945 the Government convened a conference on postwar bread and flour policy. It was agreed to recommend that flours should not be allowed to fall below a certain standard, and levels of three so-called 'token nutrients' were specified, namely $0.24 \mathrm{mg}$ thiamine, $\mathrm{x} .6 \mathrm{mg}$ nicotinic acid and $\mathrm{r} .65 \mathrm{mg}$ iron in $100 \mathrm{~g}$ flour (Great Britain. Parliament, 1945).

The Government's own advisers accepted the idea that these three nutrients could be regarded as tokens. If they were present in adequate amounts in unenriched flour many other essential nutrients were also likely to be present in favourable quantity. These advisers opposed the policy of enrichment and preferred to include in flour as much as possible of the vitamins found in the whole grain.

The representatives of the flour-milling and bread-making industries were however convinced that the public preferred white bread to any alternative. They agreed that the specified levels of token nutrients ought to be attained, but they favoured enrichment of white flour with synthetic vitamins as a means to that end.

The members of the 1945 conference agreed, however, that there should be an 
investigation to determine whether low-extraction flour enriched with the token nutrients could replace in the diet the higher-extraction flour in which these nutrients were obtained wholly from the wheat grain. The famous experiments carried out in Germany in $1947-8$ by Dr Widdowson and Professor McCance under the auspices of the Medical Research Council aimed at settling this point. The results have been published (Widdowson \& McCance, 1954) and discussed at length.

It will be remembered that during and after the war, cereals were controlled and bread was subsidized. In 1953 greater supplies made it possible to decontrol cereals (Great Britain. Parliament, r953a) but the controversy on enrichment persisted, and the Government gave effect to a compromise. They decided to permit production of flour of extraction rate below $80 \%$ and to require the three token nutrients to be added so that the minimum levels would be reached. In deference, however, to the views of their own nutritional advisers, the Government limited the payment of subsidy on bread to that made from National flours of not less than $80 \%$ extraction rate. It was also agreed that in order to facilitate the production of patent flours the milling industry should be allowed to produce National flour by selection of mill streams as well as by the 'straight-run' process. This policy, as expressed in the Flour Order, I953 (Great Britain. Parliament, I953 $b$ ) and the Bread Order, I953 (Great Britain. Parliament, $1953 c$ ) gave the consumer the choice between National bread at $7 \frac{1}{2} \mathrm{~d}$. a $1 \frac{3}{4} \mathrm{lb}$. loaf and bread made from whiter flour enriched with token nutrients but costing from $10 \frac{1}{2} \mathrm{~d}$. to Is. for a loaf of that weight. The Flour Order, I953, defined National flour as follows: "National Flour" means flour complying with the following conditions:-

(i) it shall contain the maximum quantity of wheat germ which, having regard to the type of milling, can be included in such flour;

(ii) it shall not include any coarse or added bran; and

(iii) it shall consist of wheat flour and shall either be of 80 per cent. extraction or shall be of substantially the same nature and contain substantially the same quantities and proportions of constituents as flour of 80 per cent. extraction.'

It did not turn out to be feasible to prove infringement of the Order. With no effective means of enforcement, a progressive lowering of the extraction rate occurred, so that by $1954-5$ 'subsidised National bread was being made from a flour containing significantly less vitamin $B_{1}$, and slightly less nicotinic acid and iron, than was contained in the 70 per cent. extraction enriched flour used to make unsubsidised bread'.

It might have been possible to redraft an Order and make it enforceable, but the Widdowson-McCance report made the representatives of the industry quite unwilling to accept the basic contention that with present-day diets a flour of $80 \%$ extraction is superior to a flour of lower extraction in which the three 'token' nutrients have been restored to the specified levels.

The situation confronting the Panel was thus a complicated one. Dissension on medical and scientific issues had for some years been open and serious, the compromise of 1953 had proved unsatisfactory and the time had clearly come for the Government to decide on a policy. 
Section 6 of the Report of the Panel comments on flour composition and nutritive value and the analytical results are summarized in tables.

Table I. Values for composition of flour (per $100 \mathrm{~g})$ derived from Table $\mathrm{I}$ and Appendix 3 of the Report

\begin{tabular}{llc} 
Protein (g) & I I 0 & I I.4 \\
Thiamine (mg) & 0.1 I & 0.26 \\
Nicotinic acid (mg) & 0.72 & $\mathbf{I} \cdot 20$ \\
Riboflavin (mg) & 0.035 & 0.05 \\
Pyridoxine (mg) & 0.15 & $0.25(0.29)$ \\
Pantothenic acid (mg) & $0.6(0.33)$ & $0.9(0.37)$ \\
Biotin (mg) & 0.001 I & 0.0023 \\
Folic acid (mg) & $*$ & 0.026 \\
Calcium (available) (mg) & I 8.0 & 57.0 \\
Iron (available) (mg) & I.0 & I.8 \\
\multicolumn{2}{r}{ Values in parentheses are from Table I of the Report } \\
$\quad$ Information not available.
\end{tabular}

The essential facts derived from Table $\mathrm{I}$ and Appendix 3 of the Report are shown in Table $\mathbf{I}$.

I would now like to select some points from the Report of the Panel which seem specially relevant to this symposium.

(a) The gross amount of a substance found to be present by analysis 'may include a variety of forms not all of which are equally available for absorption from the digestive tract ... . The value of one constituent of the diet may be influenced by the presence of another .... Whilst it is convenient and necessary to review the composition of flours item by item, a just estimate of the nutritive value of individual components must take into account their importance relative to the diet as a whole.' (b) Because of differences between wheats and differences in milling technique, straight-run $80 \%$ extraction flours vary significantly in composition. The differences may be increased in milling an equivalent $80 \%$ extraction flour (i.e. a National flour by the 'divides' method). 'It is not possible to prove whether any given sample of flour does or does not conform with the Flour Order definition of National flour ...... Hence the composition of flour complying with the Flour Order is not in fact a defined composition. In considering ...... their Terms of Reference, therefore, the Panel has had to take into account, firstly, National flour of the composition envisaged by the Conference on the Post-War Loaf, and secondly, flour being sold during 1955 as National flour.'

(c) 'Evidence submitted by the Department of the Government Chemist indicates that enriched low extraction flour contains "token" nutrients in amounts which are reasonably close to the requirements laid down in the Flour Order, whereas National flours milled in 1954 and 1955 , whether "straight-run" or by "divides", were notably below the required levels in Vitamin $B_{1}$ and slightly lower in nicotinic acid. Enriched low extraction flours were sometimes low in iron.' 
(d) 'The Panel believes that the immediate drop in the vitamin $B_{1}$ and nicotinic acid content of National flour after decontrol and the continuing fall since, have resulted primarily from deliberate disregard of the intention of the Flour Order rather than from such factors as variations in the character of the wheat from which the flour was milled, although these factors may have played a secondary role.'

(e) The amount of protein present in flour falls as the extraction rate falls and the proteins of the germ and bran are somewhat richer in lysine than the protein of the endosperm. However, 'for man on a mixed diet the synergic influence of proteins in other foods reduces the significance of animal experiments in which all the protein comes from one source'.

(f) Although estimates of the thiamine content of flour of $70-72 \%$ extraction vary (around $0.08 \mathrm{mg} / \mathrm{l} 00 \mathrm{~g}$ ) the Panel was satisfied that 'in the ordinary run of commercial milling' $80 \%$ extraction flour contained a good deal more (nearer $0.2 \mathrm{mg} / \mathrm{ro0} \mathrm{mg}$ ), but not perhaps the $0.24 \mathrm{mg} / 100 \mathrm{~g}$ required for enriched white flour.

(g) There is no doubt that there is less nicotinic acid in flours of lower extraction than in flours of $80 \%$ extraction. Some of the nicotinic acid and nicotinamide in wheat products, as in maize products, occurs in a bound form which cannot be utilized by the animal. There is good evidence moreover that nicotinic acid can be synthesized in the body from tryptophan which is supplied in adequate amount by the various proteins of flour. Nicotinic acid is added to low extraction flour to a minimum content of $\mathrm{r} \cdot 6 \mathrm{mg} / \mathrm{r} 00 \mathrm{~g}$ of flour and the added vitamin is well absorbed. (h) The riboflavin content of flour falls a little as the extraction rate falls from 80 to $70 \%$. This decrease was not regarded as critical. In the United Kingdom there is no legal obligation to add riboflavin to flour but in the U.S.A. a riboflavin content of $0.26 \mathrm{mg} / 100 \mathrm{~g}$ is maintained by enrichment.

(i) Although the evidence is rather meagre it seems that as the extraction rate falls from 80 to $70 \%$ the levels of pyridoxine, biotin and folic acid will also fall and the level of pantothenic acid may fall very slightly (Table 2 ).

Table 2. Estimated percentage contribution made by flour products to the dietary intake of certain vitamins on the basis of (a) $80 \%$ extraction flour, (b) Patent flour ( $40 \%$ extraction), derived from para. 6.2 I of the Report

$\begin{array}{cc}\text { (a) } 80 \% \text { flour } & \text { (b) Patent flour } \\ 39 & \text { 19 } \\ 18 & \text { I } 6 \\ 14 & 4 \\ 28 & \text { r } 5\end{array}$

(j) The fact that there is less phytic acid in flours of lower extraction is not very important when flours contain added $\mathrm{CaCO}_{3}$ in the form of creta preparata.

(k) There is less iron in low-extraction flours than in $80 \%$ extraction flour, perhaps I $\mathrm{mg} / \mathrm{r} 00 \mathrm{~g}$ as compared with $\mathrm{x} .65 \mathrm{mg} / \mathrm{roO} \mathrm{g}$ required for enriched white flour.

The Panel had the benefit of written statements and was able to take evidence orally from the delegations representing the Government's medical and scientific 
advisers and the Medical Research Council. The fact that bread, on a national average, contributes one-third of the total calories of the diet provided the starting point for the argument in favour of $80 \%$ extraction flour. National flour of $80 \%$ extraction makes it virtually certain that the diet as a whole will provide an adequate supply of protein, thiamine, nicotinic acid and iron and, in addition, such flour provides useful quantities of other essential nutrients for which there are less welldefined criteria of adequacy. If the extraction rate were lowered to $70 \%$ there would be a loss of protein, thiamine, nicotinic acid and iron, and, even if these two vitamins and iron were restored by enrichment, a reduced intake of other vitamins might in some circumstances be reflected in nutritional deficiencies.

The contrary view, argued by the representatives of the industry claimed that between National flour of $80 \%$ extraction and whiter flour of lower extraction, enriched with thiamine, nicotinic acid and iron to the levels obtaining in National flour, any differences in composition are insignificant when related to the diet as a whole.

The Panel was naturally forced to give thought to the problems of assessing nutritional requirements and to the background of the recommendations of the (U.S.A.) National Research Council: Food and Nutrition Board (1953), the Canadian Council on Nutrition (1950, 1953) and the British Medical Association: Committee on Nutrition (1950).

'All these recommendations contain arbitrarily assessed margins of safety.'

The arguments advanced for $80 \%$ extraction flour made use of the reports of the National Food Survey Committee (Ministry of Food: National Food Survey Committee, 1954; Ministry of Agriculture, Fisheries and Food: National Food Survey Committee, I955) to assess the part played by bread and flour in the diet of the population as a whole and of families varying in size or income or both. It was claimed 'that it is therefore possible that, if neither the price of bread nor the extraction rate of flour were controlled, and if enrichment were not compulsory, the lower income groups might again suffer serious lack of "token" nutrients.'

'The medical and scientific advisers to the Government insist that if there is any uncertainty about a nutritional policy it is better to err on the side of caution. They believe that nothing is gained in terms of the health of the population by providing flour of lower extraction, even when enriched with the three "token" nutrients, in place of well-made flour of 80 per cent. extraction, and that something may indeed be lost.'

The arguments advanced by the industry for enrichment may be put briefly: (a) the Flour Order, I953, had been disregarded and the 'extraction rate' was nearer $74 \%$. The downward trend could not be stopped. (b) Flour of $80 \%$ extraction is of poor technical quality and is unpopular with millers, bakers and the makers of cakes and biscuits. Bread made from it tends to be grey. "Although flour is such a major factor in nutrition there is no need for it to be a complete food in itself. The value of flour is enhanced by contributions from the remainder of the diet. If it is desirable, for overall nutritional convenience, to maintain stated levels of nutrients such as vitamin $B_{1}$, nicotinic acid and iron, it is technically possible for these to be 
added to the flour as required. The millers' scientific advisers consider it unnecessary and unrealistic to insist that flour should also contain relatively high but unspecified levels of other nutrients of which there is no evidence of shortage and no accurate knowledge of needs.'

'The millers' representatives at the Conference on the Post-War Loaf did not agree with the contention of the scientific and medical representatives that these other nutrients were of importance and it was agreed that this idea should be tested by experiment. The work of Dr E. M. Widdowson and Professor R. A. McCance in Germany was originally planned to provide such a test. The results, however, failed to demonstrate nutritional advantages of flours of higher extraction rates over lower extraction flour fortified with vitamin $B_{1}$, nicotinic acid and iron. Flour producers and flour users are of opinion that nutritional problems arising from the demand for a lower extraction flour can be met adequately by a policy of enrichment. This would not present the same difficulties as a policy of 80 per cent. extraction flour and would also ensure a more constant level of vitamin $B_{1}$, nicotinic acid and iron in flour and a greater degree of liberty to those individuals who prefer bread made from flour of superior technical quality.'

The Panel naturally studied the McCance \& Widdowson report, together with a good many commentaries on that report and on related matters. It must be well known to members of the Society that the experiments on children carried out at Wuppertal, Duisberg and Vohwinkel gave unexpected results: 'Under the particular conditions of the experiments reported here no difference could be detected between the nutritive value of the different breads except when they were given to weanling rats. Probably the most important finding concerns the high nutritive value of wheat in any of the forms customarily consumed by man. Thus it has been shown that diets in which 75 per cent. of the calories were derived from wheat flour and $2 \mathrm{I}$ per cent, from vegetables, and which contained only 8 grams of animal protein a day, provided undernourished children aged $5^{-1} 5$ years with all the nutrients required for a high rate of growth and development for a period of 18 months.'

After discussions with Professor McCance and Dr Widdowson it became clear that their experience would lead them to believe that the difference between unenriched low-extraction flour and higher-extraction flours is less than was expected at the time of the Conference on the Post-War Loaf and is probably small enough to be ignored in an otherwise well-balanced diet.

In discussing the evidence submitted to it, the Panel came to the conclusion that a diet in which the bread was made from unenriched $70 \%$ extraction flour could sometimes be short of vitamin $B_{1}$. On nicotinic acid they saw advantages in enrichment.

'Nicotinic acid can be provided in the diet and it can be made in the body from the amino-acid, tryptophan, so long as there is no pyridoxine deficiency. Much of the nicotinic acid present in cereals occurs in a bound form so that its availability is reduced. The proteins of flour, however, contribute useful amounts of tryptophan to the diet. These complications make it difficult in general to judge how far different foods share in meeting the need for nicotinic acid and in particular they blur the 
assessment. of differences in nutritional value between flours of different extraction rates. The addition of available nicotinic acid to flour of low extraction rate may well, however, be a true enrichment rather than a simple restoration.'

The part played by bread in meeting the need for riboflavin is rather small and 'the Government's plans to safeguard the uptake of riboflavin are linked to its policy for milk rather than to its policy for bread.'

'Human requirements of pyridoxine, pantothenic acid, biotin and folic acid are not known and information as to their distribution in foods and flours of various grades is far from complete. The Panel's review of the relevant literature leads them to believe that, in spite of weighty opinion to the contrary, a lowering of the extraction rate from 80 per cent. to 70 per cent. is very unlikely to lead to any nutritional disturbance from lack of these vitamins.'

'Bread made from either $8 \circ$ per cent. extraction or 70 per cent. extraction enriched flour is an excellent food. A true 80 per cent. extraction flour may give a more widely spread insurance against possible, but as yet unproved, deficiency in the rest of the diet; the 70 per cent. enriched flour gives a more certain cover against possible deficiency of the three "token" nutrients with well recognised deficiency states.'

If now the terms of reference of the Panel are recalled, the penultimate paragraph of the Report may be quoted:

'Taking into account all the circumstances, and bearing in mind particularly the needs of the vulnerable groups in the population, the Panel concludes that the available evidence does not reveal any ascertainable difference between National flour as defined in the Flour Order, I953, and flours of extraction rate less than National flour, to which vitamin $B_{1}$, nicotinic acid and iron have been restored in the amounts specified in the Flour Order, 1953, which would significantly affect the health of the population in any foreseeable circumstances. They believe, however, that differences between low extraction flour enriched as specified and low extraction flour not so enriched are significant.'

I have not tried to add much to the Report of the Panel. Indeed, my initial reaction to the invitation to give this paper--to the effect that the Report itself was the thing to read-is still a valid one.

The Society may, however, expect a few remarks from me on the reception given to the Report. It is natural for nutritionists who have lived through a period of unexampled advances in their subject and have witnessed some remarkable achievements in applying new knowledge, to have in some degree a sense of mission. It must, however, be said that the desire to serve the general welfare was not and is not confined to one side of the controversy about flour.

Some writers thought that by losing a 'battle' on flour the forces of progress would sacrifice a key position in a 'war' between their side and the 'enemy'. This was not the problem before the Panel and reactions springing from such an attitude of mind should be examined dispassionately.

In reflecting on the emerging pattern of the modes of action of vitamins, with its steady growth in clarity and reach, we must not forget that the estimated daily requirements are empirical and indeed the problem may be visualized in terms of 
replacing co-enzymes lost by side reactions-and as a rule unknown side reactions at that!

In the evidence submitted to the Panel the essential fatty acids and the tocopherols did not receive much attention, again possibly because of too little firmly established relevant information.

If we regard scientific knowledge as something which must be accepted when it is understood - the science of nutrition is then like a small island of undoubted fact in a large sea of ignorance. It has, however, a very nice beach, good for building sand castles and for bathing. We may like to pitch a tent on the shore in high summer and play on the beach but a house should be built on dry land. Scientists and science writers, in dealing professionally with nutrition policy-must distinguish between knowledge and 'could be' knowledge, however rightly they may value speculation in research.

\section{REFERENCES}

British Medical Association: Committee on Nutrition (1950). Report of the Committee on Nutrition. London: British Medical Association.

Canadian Council on Nutrition (1950). Canad. Bull. Nutr. 2, no. I.

Canadian Council on Nutrition (1953). Canad. Bull. Nutr. 3, no. 2.

Great Britain. Parliament (1945). Report of the Conference on the Post-War Loaf [Cmd. 6701]. London: H.M. Stationery Office.

Great Britain. Parliament (1953a). Decontrol of Cereals and Feedingstuffs [Cmd. 8745]. London: H.M. Stationery Office.

Great Britain. Parliament (1953b). The Flour Order, 1953. Stat. Instrum. no. 1282.

Great Britain. Parliament (1953c). The Bread Order, 1953. Stat. Instrum. no. 1283.

Great Britain. Parliament (1956), Report of the Panel on Composition and Nutritive Value of Flour [Cmd. 9757]. London: H.M. Stationery Office.

Ministry of Agriculture, Fisheries and Food: National Food Survey Committee (1955), Domestic Food Consumption and Expenditure, r953. London: H.M. Stationery Office.

Ministry of Food: National Food Survey Committee (1954). Domestic Food Consumption and Expenditure, 1952. London: H.M. Stationery Office.

National Research Council: Food and Nutrition Board (1953). Publ. nat. Res. Coun., Wash., no. 302.

Widdowson, E. M. \& McCance, R. A. (1954). Spec. Rep. Ser. med. Res. Coun., Lond., no. 287.

\section{Nutritional aspects of high-extraction flour}

\section{By H. M. Sinclair, Laboratory of Human Nutrition, University of Oxford}

\section{Introduction}

In 1945 The Nutrition Society held a one-day scientific meeting upon 'Factors affecting the nutritive value of bread as human food'. This was some months after the extraction rate of flour for human consumption had been reduced from 85 to $82.5 \%$, and shortly after the extraction rate had been further reduced to $80 \%$. Then as now the Chairman was Sir Rudolph Peters who in his introductory remarks referred to the $85 \%$ extraction flour as 'a very beautiful and wonderfully chosen foodstuff' (Peters, r946). His final words are as true now as they were then: 'I know that those who have a more purely chemical discipline often feel that it is 